\title{
Supplementation of sucupira oil in broiler diets
}

Suplementação de óleo de sucupira em rações para frangos de corte

${ }^{1}$ Castejon, Fernanda Vieira

https://orcid.org/0000-0002-1708-2829

2*Araújo, Itallo Conrado Sousa de https://orcid.org/0000-0001-8882-3180

${ }^{1}$ Santos, Bruno Moreira dos https://orcid.org/0000-0001-5722-9824
${ }^{1}$ Carvalho, Fabyola Barros

https://orcid.org/0000-0001-5900-5437

${ }^{1}$ Oliveira, Eduardo Miranda de https://orcid.org/0000-0003-4588-6901

${ }^{1}$ Edemilson Cardoso Conceição https://orcid.org/0000-0003-4113-2686

${ }^{1}$ Stringhini, José Henrique

https://orcid.org/0000-0002-3710-6963

${ }^{1}$ Department of Animal Science, Federal University of Goiás, Av. Esperança, 74690-900, Goiânia, Goiás, Brazil.

${ }^{2}$ Department of Animal Science, Federal University of Minas Gerais, Av. Antônio Carlos, 6627, 31270-901, Belo Horizonte, Minas Gerais, Brazil.

*Mail for correspondence: italloconradovet@hotmail.com

\section{RESUMO}

Objetivou-se verificar o efeito do óleo de sucupira em dietas para frangos de corte sobre o desenvolvimento intestinal, metabolizabilidade da matéria seca e do nitrogênio e desempenho de frangos de corte. Um total de 350 frangos de corte Cobb500 ${ }^{\circledR}$ de um dia de idade, machos, foram distribuídos em sete tratamentos com cinco repetições, totalizando 35 unidades experimentais com 10 aves cada. Os tratamentos consistiram em dieta controle negativo, quatro dietas com diferentes níveis de óleo de sucupira $(100 ; 500 ; 900$ e $1.300 \mathrm{mg} / \mathrm{kg})$, dieta com mananoligossacarídeo e dieta controle positivo com antibiótico. A inclusão de 900 e $1.300 \mathrm{mg}$ de óleo de sucupira prejudicou o desenvolvimento intestinal e a metabolizabilidade dos nutrientes $(\mathrm{P}<0,05)$. A inclusão de 100 ou $500 \mathrm{mg}$ de óleo de sucupira na ração para frangos de corte foi semelhante aos tratamentos controle negativo, MOS e antibiótico para as variáveis de desempenho (todas as fases estudadas) e também para a metabolizabilidade dos nutrientes ( $\mathrm{P}<0,05)$. Pode-se concluir que níveis elevados de óleo de sucupira não são recomendados na dieta de frangos de corte.

Palavras-chave: Cerrado. Frangos de corte. Óleos essenciais. Pterodon emarginatus

\section{ABSTRACT}

The objective of the present study was to ascertain the effect of sucupira oil in diets of broilers 
on gut development, dry matter and nitrogen metabolizability and broilers performance. A total of 350 one-d-old, male, Cobb500 ${ }^{\circledR}$ broiler were allotted in seven treatments with five replicates, totaling 35 experimental units with 10 birds each. The dietary treatments consisted of a negative control diet, four diets with different levels of sucupira oil $(100 ; 500 ; 900$ and 1,300 mg/kg), diet with mannanoligosaccharide and control diet with antibiotic. The inclusion of 900 and $1,300 \mathrm{mg}$ of sucupira oil impaired gut development and metabolizability of nutrients $(\mathrm{P}<0.05)$. The inclusion of 100 or $500 \mathrm{mg}$ of sucupira oil in broiler feed was similar to negative control, MOS and antibiotic treatments for performance variables (all phases studied) and also for nutrient metabolizability $(\mathrm{P}<0.05)$. It can be concluded that high levels of sucupira oil is not recommended in broilers diet.

Keywords: Broiler chicken. Cerrado vegetation; Essential oils; Pterodon emarginatus

\section{INTRODUCTION}

Antibiotic growth promoters (AGPs) has been usually included in poultry feed to improve performance and prevent diseases (BRENES \& ROURA, 2010), but since 2006 these products was banned from animal feed by The European Union countries (CASTANON, 2007). Products with alternative growth promoters' action have been tested to maintain productive indexes and final product quality, in addition to being financially viable (CHOWDHURY et al., 2018).

Phytogenic additives emerged to replace use of AGPs, including plant extracts and essential oils, has attracted increased attention to improve performance and health in poultry production (CHOWDHURY, et al., 2018). Phytogenic inhibit the growth of pathogenic microorganisms, increase mucus production, antioxidant properties and decrease ammonia production (HASHEMI \& DAVOODI, 2011). In addition, several studies on phytogenic additives like garlic, black pepper, hot red pepper and ginger, turmeric extract (Curcuma longa), citrus extract, grape seed extract (Vitis $s p$.), guava extract (Psidium guajava), chinese cinnamon essential oil (Cinnamomum zeylanicum), green tea, chilean boldo leaves (Peumus boldus), and others have shown that may improve rearing conditions, performance and healf of broilers and layers (HERNADEZ et al., 2004; SARKE et al. 2010; FASCINA et al., 2017; OLIVEIRA t al., 2018; IRIVBOJE et al. 2020).

The Cerrados biome is recognized as the richest savannah in the world and its vegetation represents $23 \%$ of the Brazilian territory, where there are a group of unique vegetable species (NERI, et al., 2007; VASCONCELOS, 2011). Several plants are native to the Cerrado and most are still little studied as to their phytotherapic properties, one of these species is the plant popularly known as sucupira.

Sucupira (Pterodon sp.) is characteristic plant of Brazilian Cerrado vegetation (LORENZI \& MATOS, 2002). There are chambers enclosing the seed and storing the aromatic oil, Dutra et al., (2012) carried out phytochemical screening of $P$. emarginatus seeds and detected the presence of flavonoids, coumarins, saponins, triterpenes and essential oil. Pterodon $s p$. presents antimicrobial activity of different antimicrobial agents products have been reported (BUSTAMANTE et al., 2010; SANTOS, et al., 2010). These characteristics make the derivatives of Pterodon $s p$. potential substitutes for AGPs in broilers feed.

However, the sucupira presents power astringent due to its chemical composition 
that presents tannins and saponins (NOLETO et al., 2018). Although broiler chickens have a low ability to distinguish flavors due to the presence of few taste buds in the oral cavity (VIEIRA, 2010), it is not known whether the odor or flavor of the sucupira oil supplementation may influence

\section{MATERIAL AND METHODS}

This experiment was conducted at a university in the city of Goiânia, Goiás, Brazil. Research on animals was conducted according to the institutional committee on animal use (case no. 030/2012). The sucupira oil was produced by cold pressing of the seeds, obtaining $15 \%$ crude oil yield. The oil resins were obtained in collaboration with a regional cooperative of sustainable production in Central Region of Brazil. Oil resins were analyzed to determine their purity and then were standardized at the Natural Products Research Laboratory, located in Goiânia, Goiás, Brazil. Sucupira oil resins contained $7.36 \% \beta$-caryophyllene.

A total of 350 one-d-old ( 32 wk breeders old) male Cobb500 ${ }^{\circledR}$ broiler distributed into seven treatments with five replicates, totaling 35 experimental units with 10 birds each. Birds were housed in galvanized steel battery cages $(0.5 \mathrm{~m} \times 0.4 \mathrm{~m} \times 0.4 \mathrm{~m})$, equipped with trough drinkers and feeders. feed consumption of the birds. The objective of this study was to study the effects of sucupira oil as a feed additive on broiler performance, nutrient digestibility and gastrointestinal tract development, comparing the levels tested with diets that used growth promoters

Water and feed were provided ad libitum. During the first 14 days the birds received $23 \mathrm{~h}$ of artificial light and 1 hour of darkness, after which they received natural light (12 h) until the end of the experiment. Birds were fed diets based on corn and soybean meal formulated to supply their nutritional requirements during pre-starter, starter and grower phases, according to Rostagno et al. (2011).

The dietary treatments consisted of a negative control diet (Table 1), and of the supplementation of different sucupira oil resin levels mixed with soybean oil and added to the control diet at the expense of corn starch, as follows: $100 \mathrm{mg}$ of sucupira (SUC100) oil resin/ $\mathrm{kg}$ of feed, $500 \mathrm{mg}$ of sucupira (SUC500) oil resin/ $\mathrm{kg}$ of feed; $900 \mathrm{mg}$ of sucupira (SUC900) oil resin $/ \mathrm{kg}$ of feed; 1,300 mg of sucupira (SUC1300) oil resin/ $\mathrm{kg}$ of feed, $800 \mathrm{mg}$ of MOS $/ \mathrm{kg}$ of feed of pre-starter and starter feed, and 400 $\mathrm{mg}$ of MOS $/ \mathrm{kg}$ of feed of grower (MOS) and $50 \mathrm{mg}$ of antibiotic Avilamycin $/ \mathrm{kg}$ of feed. 
Table 1. Ingredient composition and calculated nutritional values of the basal diets, according to rearing phase

\begin{tabular}{|c|c|c|c|}
\hline Ingredients ( $\mathrm{g} / \mathrm{Kg}$ as fed) & $\begin{array}{l}\text { Pre-starter (1- } \\
7 \text { days) }\end{array}$ & $\begin{array}{l}\text { Starter }(8-21 \\
\text { days })\end{array}$ & $\begin{array}{c}\text { Grower }(22-35 \\
\text { days })\end{array}$ \\
\hline Corn & 552.9 & 598.2 & 620.5 \\
\hline Soybean meal & 382.5 & 346.7 & 315.4 \\
\hline Soybean oil & 20.5 & 18.8 & 29.9 \\
\hline Dicalcium phosphate & 19.0 & 9.9 & 12.8 \\
\hline Limestone & 9.0 & 12.4 & 8.5 \\
\hline Salt & 5.0 & 4.9 & 4.5 \\
\hline DL-Methionine 99\% & 3.6 & 2.9 & 2.6 \\
\hline L-Lysine HCL & 2.9 & 2.1 & 1.9 \\
\hline Corn starch & 2.0 & 2.0 & 2.0 \\
\hline L-threonine $98 \%$ & 1.1 & 0.6 & 0.4 \\
\hline Vitamin Suplement $^{1}$ & 1.0 & 1.0 & 1.0 \\
\hline Mineral Suplement ${ }^{2}$ & 0.5 & 0.5 & 0.5 \\
\hline TOTAL & $1,000.0$ & $1,000.0$ & $1,000.0$ \\
\hline \multicolumn{4}{|l|}{ Calculated nutritional values } \\
\hline Metabolizable energy (kcal/kg) & $2,950.0$ & $3,000.0$ & $3,100.0$ \\
\hline Crude Protein ( $\mathrm{g} / \mathrm{Kg}$ as fed) & 222.0 & 208.0 & 195.0 \\
\hline Digestible Lysine ( $\mathrm{g} / \mathrm{Kg}$ as fed) & 13.1 & 11.7 & 10.7 \\
\hline $\begin{array}{l}\text { Digestible Methionine+Cystine } \\
(\mathrm{g} / \mathrm{Kg} \text { as fed) }\end{array}$ & 9.4 & 8.4 & 7.8 \\
\hline Calcium (g/Kg as fed) & 9.2 & 8.1 & 7.3 \\
\hline Available Phosphorus (g/Kg as fed) & 4.7 & 2.9 & 3.4 \\
\hline Sodium (g/Kg as fed) & 2.2 & 2.1 & 2.0 \\
\hline
\end{tabular}

${ }^{1}$ Supplied per kg of diet: 312,500 IU Vitamin A; 55,000 IU Vitamin D3; $375 \mathrm{mg}$ Vitamin E; $62.5 \mathrm{mg}$ Vitamin K3; $25 \mathrm{mg}$ Vitamin B1; $112.5 \mathrm{mg}$ Vitamin B2; $25 \mathrm{mg}$ Vitamin B6; $375 \mathrm{mg}$ Vitamin B12; 950 $\mathrm{mg}$ niacin; $375 \mathrm{mg}$ calcium pantothenate; $12.5 \mathrm{mg}$ folic acid; 35,000 mg DL-methionine; 15,000 $\mathrm{mg}$ choline chloride $50 \% ; 5 \mathrm{mg}$ selenium.

${ }^{2}$ Supplied per kg of diet: manganese $15,000 \mathrm{mg}$; zinc $10,000 \mathrm{mg}$; iron 10,000 mg; copper 1,600 mg; iodine $150 \mathrm{mg}$.

At the end of each week (seven, 14 and 21 d), feed consumption and weight gain were recorded. The performance indexes used were final weight, feed consumption, feed conversion and weight gain.

The metabolizability coefficients of dry matter and the crude protein were calculated after performing three metabolic assays. The 4-7-day assay was conducted with the pre-starter diet, and the 18-21 assay with starter diet and the 28-31 one with the growth diet. The three assays were carried out in a total excreta collection method, respecting the period of adaptation to the ration and to the environment and facilities, as recommended by Sakomura e Rostagno (2007). Five replications for treatment were used, with ten, nine and four birds per parcel in the first, second and third assay, repectively.

The excreta was collected twice a day (morning and afternoon) in four consecutive days. They were stored in plastic bags, identified, weighed and frozen 
for further analysis. The analysis of dry matter (MS), and nitrogen (N) (Kjeldahl method) were carried out following the methodology described by Silva e Queiroz (2002). The results were used to calculate the dry matter metabolilzability coefficients (MET. MS), nitrogen balance (BN) and nitrogen metabolizability coefficient (MET. $\mathrm{N})$ according to the methods of the Association of Official Analytical Chemists (1995).

To measure the effects of sucupira oil on the gastrointestinal tract of broilers, the relative weight of proventriculus and gizzard, intestines, pancreas and liver were investigated; length of each intestinal segment (duodenum, jejunum and ileum); height of villi, depth of crypt and relation villus: crypt of each intestinal segment (duodenum, jejunum and ileum).

For gastrointestinal tract evaluation, euthanasias of the birds were carried out, followed by collection of the organs at seven, 21 and 35 days of life. In each of the collections one bird per replication was used, totalling 105 birds, five birds per collection in each treatment. All the birds in necropsies were desensitized by inhalation of carbon dioxide and then suffered cervical displacement. The organs of the digestive system were separated and weighed individually and the length of the intestine and its portions were measured with a ruler. Segments of approximately $2.0 \mathrm{~cm}$ of the duodenum, jejunum and ileum were collected and fixed in $10 \%$ buffered formaldehyde solution for 24 hours. After fixation, the samples were stored in $70 \%$ alcohol and processed according to the methodology described by Luna (1968) and stained by the Hematoxylin - Eosin (HE) method. For intestinal histomorphometry (villus height, crypt depth and villus/crypt ratio), 10 measurements were made on each intestinal segment, per bird, resulting in 50 measurements per treatment. Measurements were made by using an optical microscope (5X) coupled to an image analyzer system (LEICA, 2012).

Statistical analysis was performed through the GLM procedure of SAS software (SAS, 2009). Normality and homogeneity of variances were evaluated by Shapiro-Wilk and Levene tests, respectively (5\%). The data were submitted to analysis of variance (ANOVA) and the averages were compared by the Tukey's test at 5\% significance. Nonparametric ANOVA was used for data that did not meet normality and homoscedasticity, with means being compared by the Kruskal-Wallis test (5\%).

\section{RESULTS AND DISCUSSION}

It was not possible to find in the literature papers that they evaluated different doses of inclusion of the sucupira oil on broiler diets and the comparison of these levels compared to other additives and growth promoters. In this way, the results obtained are fundamental to the continuity of the study of this product in poultry diets, since there were identified levels acceptable in which the results resemble other additives. The average weight of allotment of the chicks was the same for all treatments $(\mathrm{P}>0.05)$ studied $(40.5 \pm 0.3 \mathrm{~g})$. When the performance results for all phases were analyzed (Table 2), it is possible to observe that for performance from one to seven days, the average weight, weight gain, feed consumption and food conversion were affected by the treatments studied $(\mathrm{P}<0.05)$. 
Table 2. Performance of broilers fed with diets contents sucupira oil

\begin{tabular}{lcccc}
\hline \multicolumn{5}{c}{1 to $7 \mathrm{~d}$ of age } \\
\hline Treatments & $\begin{array}{c}\text { Feed } \\
\text { intake } \\
(\mathrm{g})\end{array}$ & Body weight $(\mathrm{g})$ & Body Weight gain $(\mathrm{g})$ & Feed conversion ratio \\
\hline Control diet & $105.6 \mathrm{a}$ & $142.2 \mathrm{a}$ & $102.1 \mathrm{a}$ & $1.036 \mathrm{a}$ \\
SUC100 & $107.2 \mathrm{a}$ & $138.2 \mathrm{a}$ & $98.0 \mathrm{a}$ & $1.094 \mathrm{ab}$ \\
SUC500 & $107.0 \mathrm{a}$ & $140.2 \mathrm{a}$ & $99.8 \mathrm{a}$ & $1.074 \mathrm{ab}$ \\
SUC900 & $89.5 \mathrm{~b}$ & $119.0 \mathrm{~b}$ & $78.6 \mathrm{~b}$ & $1.14 \mathrm{bc}$ \\
SUC1300 & $76.7 \mathrm{~b}$ & $103.8 \mathrm{c}$ & $63.8 \mathrm{c}$ & $1.205 \mathrm{c}$ \\
MOS & $110.9 \mathrm{a}$ & $142.0 \mathrm{a}$ & $101.7 \mathrm{a}$ & $1.092 \mathrm{ab}$ \\
Avilamycin & $115.6 \mathrm{a}$ & $147.6 \mathrm{a}$ & $107.2 \mathrm{a}$ & $1.079 \mathrm{ab}$ \\
\hline P-value & $<0.0001$ & $<0.0001$ & $<0.0001$ & 0.0027 \\
CV (\%) & 6.55 & 4.84 & 7.02 & 4.38 \\
\hline \multicolumn{5}{c}{1 to $14 \mathrm{~d}$ of age } \\
\hline
\end{tabular}

\begin{tabular}{|c|c|c|c|c|}
\hline Treatments & $\begin{array}{l}\text { Feed } \\
\text { intake } \\
(\mathrm{g})\end{array}$ & $\begin{array}{c}\text { Body weight } \\
(\mathrm{g})\end{array}$ & Body Weight gain (g) & Feed conversion ratio \\
\hline Control diet & $417.2 \mathrm{a}$ & $376.4 \mathrm{a}$ & $336.3 \mathrm{a}$ & 1.241 \\
\hline SUC100 & $422.7 \mathrm{a}$ & $379.0 \mathrm{a}$ & $338.8 \mathrm{a}$ & 1.248 \\
\hline SUC500 & $414.2 \mathrm{a}$ & $370.1 \mathrm{a}$ & $329.7 \mathrm{a}$ & 1.257 \\
\hline SUC900 & $299.4 b$ & $270.5 b$ & $230.2 b$ & 1.301 \\
\hline SUC1300 & $260.8 \mathrm{~b}$ & $239.8 \mathrm{~b}$ & $199.7 \mathrm{~b}$ & 1.311 \\
\hline MOS & $429.0 \mathrm{a}$ & $378.0 \mathrm{a}$ & $337.7 \mathrm{a}$ & 1.272 \\
\hline Avilamycin & $440.8 \mathrm{a}$ & $385.2 \mathrm{a}$ & $344.8 \mathrm{a}$ & 1.279 \\
\hline P-value & $<0.0001$ & $<0.0001$ & $<0.0001$ & 0.1700 \\
\hline $\mathrm{CV}(\%)$ & 4.97 & 5.22 & 5.89 & 3.20 \\
\hline \multicolumn{5}{|c|}{1 to $21 \mathrm{~d}$ of age } \\
\hline Treatments & $\begin{array}{l}\text { Feed } \\
\text { intake } \\
(\mathrm{g})\end{array}$ & $\begin{array}{c}\text { Body weight } \\
(\mathrm{g})\end{array}$ & Body Weight gain (g) & Feed conversion ratio \\
\hline Control diet & $961.6 \mathrm{a}$ & $743.7 \mathrm{a}$ & $703.5 \mathrm{a}$ & 1.367 \\
\hline SUC100 & $977.9 \mathrm{a}$ & $761.0 \mathrm{a}$ & $720.8 \mathrm{a}$ & 1.356 \\
\hline SUC500 & $958.2 \mathrm{a}$ & $744.9 \mathrm{a}$ & $704.4 \mathrm{a}$ & 1.360 \\
\hline SUC900 & $704.3 \mathrm{~b}$ & $565.1 \mathrm{~b}$ & $524.7 \mathrm{~b}$ & 1.343 \\
\hline SUC1300 & $632.7 \mathrm{~b}$ & $498.3 \mathrm{c}$ & $458.3 \mathrm{c}$ & 1.382 \\
\hline MOS & $979.2 \mathrm{a}$ & $747.1 \mathrm{a}$ & $706.8 \mathrm{a}$ & 1.387 \\
\hline Avilamycin & $987.2 \mathrm{a}$ & $754.7 \mathrm{a}$ & $714.2 \mathrm{a}$ & 1.383 \\
\hline P-value & $<0.0001$ & $<0.0001$ & $<0.0001$ & 0.3043 \\
\hline CV (\%) & 4.84 & 4.50 & 4.79 & 2.57 \\
\hline
\end{tabular}




\begin{abstract}
${ }^{\mathrm{a}-\mathrm{c}}$ Means within the same column with different letters are significantly different by Tukey test $(\mathrm{P}<$ $0.05)$.

MOS - mannanoligosaccharide.

$\mathrm{CV}$ - Coefficient of variation.
\end{abstract}

The inclusion of 900 and $1,300 \mathrm{mg} / \mathrm{kg}$ of the dietary sucupira oil has reduced the feed intake, body weight and body weight gain for the pre-starter diet $(\mathrm{P}<0.05)$ compared to the other treatments $(\mathrm{P}>0.05)$. Worse feed conversion (1.205) was observed for chicks that suppplemented with $1,300 \mathrm{mg} / \mathrm{kg}$ of sucupira oil compared to other treatments, being similar to the birds fed $900 \mathrm{mg} / \mathrm{kg}$ of the oil. The best feed conversion ratio was observed in the birds that received the control diet, in comparison to the ones that received 900 or $1,300 \mathrm{mg} / \mathrm{kg}$ of sucupira oil in the feed $(\mathrm{P}<0.05)$, but the other treatments were similar between them $(\mathrm{P}>0.05)$.

For the performance of one to fourteen days of age, the results of feed intake, body weight and body weight gain were worse in treatments with 900 and $1,300 \mathrm{mg}$ of sucupira oil in the feed. However, unlike seven days of age, these reductions were not enough to change the feed conversion ratio. The feed consumption was less than 21 days for the group that received 900 or $1,300 \mathrm{mg}$ of the sucupira oil in the feed $(\mathrm{P}<0.05)$ in relation to the other treatments studied. The average body weight and body weight gain were worse for the group that received $1,300 \mathrm{mg}$ of the feed $(\mathrm{P}<0.05)$ in relation to the other treatments studied. The feed conversion ratio in the phase of one to 21 days was not influenced by the treatments studied.

The use of plant extracts or essential oils as food additives is still widely studied, even after more than 10 years of banning the use of growth promoters by the European Union. Studies still persist due to several countries not having such a ban, however, there is a greater critical analysis on the part of the consumer who is looking for free antibiotics diets, which reinforces the need for research to find alternative food additives with antimicrobial capacity. In the present study, the worst broiler performance that received the dosages of 900 and 1,300 $\mathrm{mg}$ of sucupira oil in the diet may be associated with the bitter taste of the product, since they reduced feed intake and this resulted in worsening of the other performance indexes. According to Vieira (2010), the broilers do not have good ability to distinguish flavors, however it is possible to infer that the high concentration of tannins present in the sucupira oil made the diet astringent which possibly reduced its consumption. Despite the low capacity of the broilers to distinguish flavors, overall they present 24 gustatory buttons in the lower portion of the tongue which guarantees a selection of the food. Extracts and herbs added to the animal feed can improve the palatability of the feed, thus increasing production performance (WINDISCH et al., 2007).

The metabilizability coefficient of the dry matter (Table 3) was not influenced by the treatments in the period from four to seven and from 18 to 21 days $(\mathrm{P}>0.05)$. However, there was an effect for the period of 28 to 31 days $(\mathrm{P}>0.05)$ in dry matter metabolizability that had the worst results for the diet supplemented with 900 and $1,300 \mathrm{mg}$ of sucupira oil compared to the group that received avilamycin in feed, and the other treatments did not differ from each other $(\mathrm{P}>0.05)$. Nitrogen balance (Table 3 ) was influenced by the treatments studied for all phases of rearing $(\mathrm{P}<0.05)$. For the four 
to seven-day phase, the worst nitrogen balance was observed in the group that received $1,300 \mathrm{mg}$ of sucupira oil in comparison to the group that received antibiotic in the diet $(\mathrm{P}<0.05)$, and the other treatments did not differ from each other $(\mathrm{P}>0.05)$. For the 18 to 21 day phase, a better nitrogen balance was observed for the group that received antibiotic in the diet, in relation to the group that received 500; 900;
1,300 mg of sucupira oil in the feed, MOS and Negative Control diet $(\mathrm{P}<0.05)$. The worst nitrogen balance was observed in the group that received to the group that received $1,300 \mathrm{mg}$ of sucupira oil in the feed $(\mathrm{P}<0.05)$ compared to the control group, level of 100 and 500 of sucupira oil and group that received antibiotic, similar to the MOS group and $900 \mathrm{mg}$ of sucupira oil $(\mathrm{P}>0.05)$. 
Table 3. Metabolizability coefficients of dry matter and nitrogen balance of broilers fed with diets contents sucupira oil

\begin{tabular}{|c|c|c|}
\hline \multicolumn{3}{|c|}{4 to $7 \mathrm{~d}$ of age } \\
\hline Treatments & DMMC (\%) & Nitrogen balance $(\%)$ \\
\hline Control diet & 72.2 & $50.2 \mathrm{ab}$ \\
\hline SUC100 & 72.1 & $51.7 \mathrm{ab}$ \\
\hline SUC500 & 72.2 & $55.3 \mathrm{ab}$ \\
\hline SUC900 & 71.0 & $54.0 \mathrm{ab}$ \\
\hline SUC1300 & 69.0 & $44.8 \mathrm{~b}$ \\
\hline MOS & 73.5 & $54.5 \mathrm{ab}$ \\
\hline Avilamycin & 71.8 & $56.8 \mathrm{a}$ \\
\hline P-value & 0.2178 & 0.0189 \\
\hline $\mathrm{CV}(\%)$ & 3.58 & 9.76 \\
\hline \multicolumn{3}{|c|}{18 to $21 \mathrm{~d}$ of age } \\
\hline Treatments & DMMC (\%) & Nitrogen balance $(\%)$ \\
\hline Control diet & 74.2 & $46.7 \mathrm{c}$ \\
\hline SUC100 & 73.9 & $53.5 \mathrm{ab}$ \\
\hline SUC500 & 73.9 & $49.6 \mathrm{bc}$ \\
\hline SUC900 & 74.5 & $43.5 \mathrm{~cd}$ \\
\hline SUC1300 & 74.0 & $42.0 \mathrm{~d}$ \\
\hline MOS & 74.1 & $43.7 \mathrm{~cd}$ \\
\hline Avilamycin & 74.2 & $56.4 \mathrm{a}$ \\
\hline P-value & 0.7803 & $<0.0001$ \\
\hline $\mathrm{CV}(\%)$ & 1.73 & 6.05 \\
\hline \multicolumn{3}{|c|}{28 to $31 \mathrm{~d}$ of age } \\
\hline Treatments & DMMC (\%) & Nitrogen balance $(\%)$ \\
\hline Control diet & 73.9ab & $48.9 \mathrm{ab}$ \\
\hline SUC100 & $74.1 \mathrm{ab}$ & $54.4 \mathrm{ab}$ \\
\hline SUC500 & $72.4 \mathrm{ab}$ & $61.8 \mathrm{a}$ \\
\hline SUC900 & $71.0 \mathrm{~b}$ & $47.2 \mathrm{~b}$ \\
\hline SUC1300 & $71.2 \mathrm{~b}$ & $44.1 b$ \\
\hline MOS & $75.9 \mathrm{ab}$ & $53.3 \mathrm{ab}$ \\
\hline Avilamycin & $77.0 \mathrm{a}$ & $62.3 \mathrm{a}$ \\
\hline P-value & 0.0419 & 0.0003 \\
\hline $\mathrm{CV}(\%)$ & 3.78 & 11.80 \\
\hline
\end{tabular}

${ }^{\mathrm{a}-\mathrm{c}}$ Means within the same column with different letters are significantly different by Tukey test $(\mathrm{P}<$ $0.05)$.

DMMC- Dry matter metabolilzability coefficients.

MOS - mannanoligosaccharide.

$\mathrm{CV}$ - Coefficient of variation.

The nitrogen balance obtained from 28 to 31 days of age was influenced by the treatments studied $(\mathrm{P}<0.05)$. The highest results were obtained for chicks that received $500 \mathrm{mg}$ of sucupira oil or antibiotics in the ration in relation to 900 or $1,300 \mathrm{mg} / \mathrm{kg}$ groups (Table 3). 
The sucupira oil when used in the largest concentrations (900 or $1,300 \mathrm{mg} / \mathrm{kg}$ of ration) left the diet with characteristic flavour and odor. In study with the use of sucupira oil in the feed of broilers in the dosage of $500 \mathrm{mg} / \mathrm{kg}$ of diet, Noleto et al. (2018) found less feed intake from 1 to 14 and 1 to 21 days and also attributed to the unpleasant taste and odor of the feed. However, in the present study the $500 \mathrm{mg} / \mathrm{kg}$ group did not distinguish from the control group, $100 \mathrm{mg} / \mathrm{kg}$, MOS and avilamycin groups for the feed intake. The other performance parameters were also worsened in the $900 \mathrm{mg} / \mathrm{kg}$ and 1,300 $\mathrm{mg} / \mathrm{kg}$ groups, possibly due to low feed intake throughout the poultry rearing period.

The length of the gastrointestinal tract and the relative weight of proentriculus + gizzard were not influenced $(\mathrm{P}>0.05)$ by the treatments studied at the seven days of age (Table 4). On the other hand, the relative weight of the liver and pancreas were affected by the treatments $(\mathrm{P}<0.05)$. The largest liver relative weight was found in the $100 \mathrm{mg} / \mathrm{kg}$ of sucupira oil compared to the $1,300 \mathrm{mg} / \mathrm{kg}$ group $(\mathrm{P}<0.05)$, and the other groups did not differ $(\mathrm{P}>0.05)$. The smallest pancreas weight was found in the control group chicks and $1,300 \mathrm{mg} / \mathrm{kg}$ group, when compared to $500 \mathrm{mg} / \mathrm{kg}$ chicks $(\mathrm{P}<0.05)$. 
Table 4. Gastrointestinal tract evaluation of broilers fed with diets contents sucupira oil

\begin{tabular}{|c|c|c|c|c|c|}
\hline & \multicolumn{5}{|c|}{$7 \mathrm{~d}$ of age } \\
\hline Treatments & $\begin{array}{c}\text { Small } \\
\text { intestine } \\
(\mathrm{cm})\end{array}$ & $\begin{array}{c}\text { Large } \\
\text { intestine } \\
(\mathrm{cm})\end{array}$ & $\begin{array}{l}\text { Pro-ventricular } \\
+ \text { gizzard }(\%)\end{array}$ & Liver (\%) & $\begin{array}{c}\text { Pancreas } \\
(\%)\end{array}$ \\
\hline Control diet & 80.6 & 9.2 & 5.61 & $3.91 \mathrm{ab}$ & $0.45 b$ \\
\hline SUC100 & 81.4 & 9.6 & 5.76 & $4.02 \mathrm{a}$ & $0.57 \mathrm{ab}$ \\
\hline SUC500 & 88.6 & 10.0 & 5.80 & $3.62 \mathrm{ab}$ & $0.65 \mathrm{a}$ \\
\hline SUC900 & 91.8 & 9.8 & 5.64 & $3.73 \mathrm{ab}$ & $0.52 \mathrm{ab}$ \\
\hline SUC1300 & 81.8 & 8.2 & 5.98 & $3.43 b$ & $0.46 \mathrm{~b}$ \\
\hline MOS & 80.6 & 9.2 & 5.40 & $3.61 \mathrm{ab}$ & $0.55 \mathrm{ab}$ \\
\hline Avilamycin & 85.0 & 10.0 & 5.01 & $3.57 \mathrm{ab}$ & $0.49 \mathrm{ab}$ \\
\hline P-value & 0.120 & 0.270 & 0.080 & 0.020 & 0.020 \\
\hline \multirow[t]{2}{*}{ CV $(\%)$} & 7.50 & 13.05 & 8.62 & 7.05 & 17.21 \\
\hline & \multicolumn{5}{|c|}{$21 \mathrm{~d}$ of age } \\
\hline Treatments & $\begin{array}{c}\text { Small } \\
\text { intestine } \\
(\mathrm{cm})\end{array}$ & $\begin{array}{c}\text { Large } \\
\text { intestine } \\
(\mathrm{cm})\end{array}$ & $\begin{array}{l}\text { Pro-ventricular } \\
\text { +gizzard }(\%)\end{array}$ & Liver (\%) & $\begin{array}{c}\text { Pancreas } \\
(\%)\end{array}$ \\
\hline Control diet & 119.2 & $13.0 \mathrm{ab}$ & $2.62 \mathrm{abc}$ & 2.65 & $0.37 \mathrm{ab}$ \\
\hline SUC100 & 128.0 & $13.0 \mathrm{ab}$ & $2.50 \mathrm{c}$ & 2.73 & $0.34 \mathrm{ab}$ \\
\hline SUC500 & 136.2 & $13.4 \mathrm{a}$ & $2.58 b c$ & 2.93 & $0.38 \mathrm{ab}$ \\
\hline SUC900 & 119.8 & $11.0 \mathrm{ab}$ & $3.08 \mathrm{a}$ & 2.85 & $0.36 \mathrm{ab}$ \\
\hline SUC1300 & 124.4 & $10.4 b$ & $2.98 \mathrm{ab}$ & 2.89 & $0.38 \mathrm{a}$ \\
\hline MOS & 133.4 & $13.0 \mathrm{ab}$ & $2.49 \mathrm{c}$ & 2.54 & $0.27 b$ \\
\hline Avilamycin & 127.4 & $13.8 \mathrm{a}$ & $2.49 \mathrm{c}$ & 2.47 & $0.31 \mathrm{ab}$ \\
\hline P-value & 0.489 & 0.006 & 0.006 & 0.032 & 0.021 \\
\hline \multirow[t]{2}{*}{$\mathrm{CV}(\%)$} & 11.70 & 11.61 & 8.66 & 8.84 & 14.36 \\
\hline & \multicolumn{5}{|c|}{$35 \mathrm{~d}$ of age } \\
\hline Treatments & $\begin{array}{c}\text { Small } \\
\text { intestine } \\
(\mathrm{cm})\end{array}$ & $\begin{array}{c}\text { Large } \\
\text { intestine } \\
(\mathrm{cm})\end{array}$ & $\begin{array}{l}\text { Pro-ventricular } \\
\text { + gizzard }(\%)\end{array}$ & Liver (\%) & $\begin{array}{c}\text { Pancreas } \\
(\%)\end{array}$ \\
\hline Control diet & 140.2 & 17.8 & 1.97 & $1.73 b$ & 0.21 \\
\hline SUC100 & 150.8 & 18.4 & 1.96 & $1.72 b$ & 0.23 \\
\hline SUC500 & 14.0 & 19.6 & 2.03 & $1.77 b$ & 0.19 \\
\hline SUC900 & 151.4 & 17.2 & 2.13 & $2.19 \mathrm{a}$ & 0.18 \\
\hline SUC1300 & 142.4 & 18.4 & 2.09 & $2.23 \mathrm{a}$ & 0.21 \\
\hline MOS & 135.2 & 16.0 & 2.16 & $1.96 \mathrm{ab}$ & 0.18 \\
\hline Avilamycin & 136.6 & 16.2 & 2.11 & $1.81 \mathrm{~b}$ & 0.19 \\
\hline P-value & 0.662 & 0.399 & 0.823 & $<0.0001$ & 0.365 \\
\hline CV (\%) & 12.06 & 13.49 & 12.49 & 8.97 & 21.52 \\
\hline
\end{tabular}

${ }^{\mathrm{a}-\mathrm{b}}$ Means within the same column with different letters are significantly different by Tukey test $(\mathrm{P}<$ $0.05)$.

MOS - mannanoligosaccharide.

$\mathrm{CV}$ - Coefficient of variation. 
Moreover, it is possible to observe worsening on the gastrointestinal development of the broilers fed $900 \mathrm{mg} / \mathrm{kg}$ and $1,300 \mathrm{mg} / \mathrm{kg}$ groups which reinforces that the action of the tannins may have been fundamental for the low performance of the birds. The ration containing avilamycin provided good results of performance, intestinal development and also the metabolizability of the dry matter and nitrogen. The use of antimicrobials as growth promoters can have good performance results (RAMOS et al., 2014) and also improves the use of dietary nutrients (BORSATTI et al., 2016) when compared to diets using phytogenic additives and prebiotics. However, the results of performance, intestinal development and nutrient metabolizatibility of the group that received lower doses of sucupira oil resembled the group that received avilamycin in the ration.

For the results of 21 days of rearing, there was a difference in the length of the large intestine of the chickens. The difference perceived in the length of the total intestine was between the group that received 1,300 $\mathrm{mg} / \mathrm{kg}$ treatment which was shorter than $500 \mathrm{mg} / \mathrm{kg}$ birds. The other treatments were similar from each other $(\mathrm{P}>0.05)$. Higher relative weight of the proventriculus + gizzards were observed for the negative control $(\mathrm{P}<0.05)$. In the relative weight of the pancreas at $14 \mathrm{~d}$, a difference was found between the $1,300 \mathrm{mg} / \mathrm{kg}$ sucupira oil and the group fed $\operatorname{MOS}(\mathrm{P}<0.05)$, with no differences between the other treatments $(\mathrm{P}>0.05)$. At 35 days of age, there a significant difference was observed only for liver relative weight $(\mathrm{P}<0.05)$. The heavier livers were found for the $900 \mathrm{mg} / \mathrm{kg}$ and $1,300 \mathrm{mg} / \mathrm{kg}$ groups in relation to the other treatments $(\mathrm{P}<0.05)$, with no difference to the MOS group $(\mathrm{P}>0.05)$.
The histomorphometric analysis of the intestinal segments of the birds for the ages of seven and 21 is presented in Table 5. At seven days, in the duodenum the height of villus for $500 \mathrm{mg} / \mathrm{kg}$ was similar to the avilamycin, being both larger than the other treatments $(\mathrm{P}<0.05)$. In the duodenum deeper crypts were found in the treatments $500 \mathrm{mg} / \mathrm{kg}$ and $1,300 \mathrm{mg} / \mathrm{kg}$ groups $(\mathrm{P}<0.05)$ in relation to the negative control and $1,300 \mathrm{mg} / \mathrm{kg}$. Deeper crypts were found in the treatments $900 \mathrm{mg} / \mathrm{kg}$ and MOS groups $(\mathrm{P}<0.05)$ in relation to the negative control $(\mathrm{P}<0.05)$. No differences were observed in the villus-crypt ratio between the treatments $(\mathrm{P}>0.05)$. In the jejunum, the $100 \mathrm{mg} / \mathrm{kg}$ and $1,300 \mathrm{mg} / \mathrm{kg}$ groups made possible smaller heights of villus compared to the negative control, MOS and avilamycin groups $(\mathrm{P}<0.05)$. The 500 $\mathrm{mg} / \mathrm{kg}$ and $900 \mathrm{mg} / \mathrm{kg}$ groups presented deeper crypts in jejunum compared to the other levels of inclusion $(\mathrm{P}<0.05)$. Already in the villus-crypt relationship of this segment, there were no differences between the levels of inclusion, which were similar to the antibiotic $(\mathrm{P}>0.05)$. The control group was similar to the treatment with MOS (the ones with higher values), and both were superior to the other treatments studied $(\mathrm{P}<0.05)$. 
Table 5. Intestinal histomorphometry evaluation of broilers fed with diets contents sucupira oil (seven and $21 \mathrm{~d}$ )

\begin{tabular}{|c|c|c|c|c|c|c|c|c|c|}
\hline \multirow{3}{*}{$\begin{array}{l}\text { Items } \\
\text { Treatment } \\
\end{array}$} & \multicolumn{9}{|c|}{7 days } \\
\hline & \multicolumn{3}{|c|}{ Duodenum } & \multicolumn{3}{|c|}{ Jejunum } & \multicolumn{3}{|c|}{ Ileum } \\
\hline & Vilus $(\square \mathrm{m})$ & Crypt $(\square \mathrm{m})$ & $\mathrm{V} / \mathrm{C}$ & Vilus ( $\square \mathrm{m})$ & Crypt $(\square \mathrm{m})$ & $\mathrm{V} / \mathrm{C}$ & Vilus $(\square \mathrm{m})$ & Crypt $(\square \mathrm{m})$ & $\mathrm{V} / \mathrm{C}$ \\
\hline Control diet & $793.8 \mathrm{c}$ & $200.8 \mathrm{c}$ & 4.07 & $564.1 \mathrm{ab}$ & $133.0 \mathrm{~b}$ & $4.40 \mathrm{a}$ & $478.8 \mathrm{ab}$ & $129.6 b$ & $3.73 a$ \\
\hline SUC100 & $771.6 \mathrm{c}$ & $210.0 \mathrm{bc}$ & 3.85 & $437.3 \mathrm{c}$ & $172.8 \mathrm{~b}$ & $2.53 b$ & $519.6 \mathrm{a}$ & $172.6 \mathrm{a}$ & $3.03 \mathrm{abc}$ \\
\hline SUC500 & $1,066.8^{\mathrm{a}}$ & $295.3 a$ & 3.61 & $559.0 \mathrm{ab}$ & $215.1 \mathrm{a}$ & $2.59 \mathrm{~b}$ & $405.0 \mathrm{c}$ & $164.9 \mathrm{a}$ & $2.46 \mathrm{c}$ \\
\hline SUC900 & $883.2 \mathrm{bc}$ & $275.9 \mathrm{ab}$ & 3.20 & $502.6 \mathrm{bc}$ & $223.2 \mathrm{a}$ & $2.28 \mathrm{~b}$ & $448.9 b c$ & $127.5 b$ & $3.52 \mathrm{ab}$ \\
\hline SUC1300 & $856.6 \mathrm{bc}$ & $289.9 \mathrm{a}$ & 2.96 & $461.5 \mathrm{c}$ & $156.0 \mathrm{~b}$ & $2.96 \mathrm{~b}$ & $424.5 \mathrm{bc}$ & $123.3 \mathrm{~b}$ & $3.46 a b$ \\
\hline MOS & $944.2 b$ & $260.7 \mathrm{ab}$ & 3.65 & $615.0 \mathrm{a}$ & $145.7 \mathrm{~b}$ & $4.32 \mathrm{a}$ & $466.7 \mathrm{abc}$ & $160.6 \mathrm{a}$ & $2.93 b c$ \\
\hline Avilamycin & $1,076.8^{\mathrm{a}}$ & $247.6 \mathrm{abc}$ & 4.39 & $549.4 \mathrm{ab}$ & $172.1 \mathrm{~b}$ & $3.22 b$ & $519.6 \mathrm{a}$ & $149.8 \mathrm{ab}$ & $3.51 \mathrm{ab}$ \\
\hline P-value & 0.0002 & 0.0100 & 0.18 & 0.002 & 0.001 & 0.002 & 0.01 & 0.003 & 0.012 \\
\hline \multirow[t]{2}{*}{ CV (\%) } & 7.3 & 12.0 & 17.4 & 8.0 & 12.6 & 18.4 & 7.8 & 8.8 & 11.7 \\
\hline & \multicolumn{9}{|c|}{21 days } \\
\hline Control diet & $1,432.3 \mathrm{ab}$ & $300.2 \mathrm{bc}$ & 4.81 & $852.4 \mathrm{bcd}$ & $221.8 \mathrm{a}$ & $3.85 \mathrm{de}$ & 581.6 & 176.3 & 3.31 \\
\hline SUC100 & $1,402.7 \mathrm{ab}$ & $316.0 \mathrm{~b}$ & 4.46 & $827.0 \mathrm{~cd}$ & $215.6 \mathrm{a}$ & $3.95 \mathrm{cde}$ & 563.8 & 223.4 & 2.54 \\
\hline SUC500 & $1,540.6^{\mathrm{a}}$ & $309.0 \mathrm{~b}$ & 3.56 & $972.9 \mathrm{a}$ & $159.8 \mathrm{~b}$ & $6.14 \mathrm{a}$ & 622.1 & 204.8 & 3.04 \\
\hline SUC900 & $1,304.2 b c$ & $387.7 \mathrm{a}$ & 3.36 & $816.9 d$ & $232.5 \mathrm{a}$ & $3.54 \mathrm{e}$ & 564.9 & 185.9 & 3.04 \\
\hline SUC1300 & $1,440.9 \mathrm{ab}$ & $406.2 a$ & 3.56 & $934.5 \mathrm{abc}$ & $192.1 \mathrm{ab}$ & $4.90 \mathrm{cb}$ & 487.5 & 187.8 & 2.60 \\
\hline MOS & $1,032.6 \mathrm{~d}$ & $235.7 \mathrm{~d}$ & 4.40 & $965.5 \mathrm{ab}$ & $200.6 \mathrm{ab}$ & 4.81ced & 619.7 & 195.3 & 3.19 \\
\hline Avilamycin & $1,235.2 \mathrm{c}$ & $264.2 \mathrm{~cd}$ & 4.67 & $805.5 \mathrm{~d}$ & $155.9 \mathrm{~b}$ & $5.16 \mathrm{~b}$ & 638.8 & 211.5 & 3.04 \\
\hline P-value & $<0.0001$ & $<0.0001$ & 0.5121 & 0.0138 & 0.0344 & 0.0004 & 0.3296 & 0.2970 & 0.0538 \\
\hline CV (\%) & 6.16 & 6.76 & 26.46 & 7.02 & 14.67 & 11.39 & 13.51 & 12.26 & 10.15 \\
\hline
\end{tabular}


At seven days, in the ileum, $100 \mathrm{mg} / \mathrm{kg}$ sucupira oil and avilamycin showed greater villus length values than the other levels of inclusion $(\mathrm{P}<0.05)$, however they did not differ from negative control, and MOS groups. Deeper crypts were observed in the treatments $100 \mathrm{mg} / \mathrm{kg}, 500 \mathrm{mg} / \mathrm{kg}$ and MOS, in relation to the other treatments, except the avilamycin group. Conclusive differences in the villus-crypt ratio are only observed between the diet negative control and the $500 \mathrm{mg} / \mathrm{kg}$. This level presented less relationship between the levels of inclusion, being inferior to negative control and antibiotic.

At $21 \mathrm{~d}$, birds consuming feed added to the levels of sucupira oil were not different in the villus height of the duodenum compared to the negative control group (Table 5), but the results of the $100 ; 500$ and $1,300 \mathrm{mg} / \mathrm{kg}$ were greater than the avilamycin $(\mathrm{P}<0.05)$. The MOS treatment had the smallest values for villus height, however it was similar to treatment $900 \mathrm{mg} / \mathrm{kg}$ of sucupia oil. For the crypt depth for $900 \mathrm{mg} / \mathrm{kg}$ and $1,300 \mathrm{mg} / \mathrm{kg}$ resulted in higher values $(\mathrm{P}<0.05)$ when they were compared to other treatments. The smallest crypt depth values were found for MOS compared to negative control, 100 $\mathrm{mg} / \mathrm{kg} ; 500 \mathrm{mg} / \mathrm{kg} ; 900 \mathrm{mg} / \mathrm{kg}$ and 1,300 $\mathrm{mg} / \mathrm{kg}$ of sucupia oil in feed $(\mathrm{P}<0.05)$. Due to the higher values of villus height for the inclusions of the sucupira oil have been accompanied by greater crypt depth values, the villus-crypt ratio has not been altered $(\mathrm{P}>0.05)$ by the inclusion of any additive. In the jejunum, differences were observed between the villus height of the $500 \mathrm{mg} / \mathrm{kg}$ (higher) compared to negative control, 100 and $900 \mathrm{mg} / \mathrm{kg}$ of sucupia oil in feed and avilamycin group $(\mathrm{P}<0.05)$. The level of $1,300 \mathrm{mg} / \mathrm{kg}$ that was similar avilamycin $(\mathrm{P}>0.05)$. The negative control group and $100 \mathrm{mg} / \mathrm{kg}$ and $900 \mathrm{mg} / \mathrm{kg}$ produced greater crypt depth values than the avilamycin treatment and the $500 \mathrm{mg} / \mathrm{kg}(\mathrm{P}<0.05)$. The relationship villus-crypt group $500 \mathrm{mg} / \mathrm{kg}$ presented the highest value among all treatments, indicating possible increments in intestinal morphology by using this level of inclusion of sucupira oil at that age. At 21 days, in the ileum, none of the additives promoted changes in the analyzed variables $(\mathrm{P}>0.05)$.

Phytogenic can produce morphological changes in the intestinal epithelium and organs morphometry (HAZRATI et al., 2005). Changes in the morphology of the gastrointestinal tract and in tissues caused by phytogenic can provide information on the possible benefits to the gastrointestinal tract (WINDISCH et al., 2007). However, experimental data of body weight and intestinal morphometry with the use of phytogenic are quite variable, and differ from those obtained in this experiment using sucupira oil. In the study done by Kirkpinar, Bora \& Özdemir (2011), when using isolated oregano and garlic or in association in poultry diets, no significant differences were observed in the biometrics of the organs.

Using essential oil of thyme and star anise, Amad et al. (2011) didn't find any differences in the average weight of liver, heart, kidneys and spleen. Already Silva et al. (2011), with the addition of red pepper oil in the diet of chickens, verified a reduction in the relative weight of the intestines when compared to the diet without growth promoter. In the most recent study, with the use of integral bran of pink pepper, Gonçalves et al. (2017) found that the antibiotics can be wholly or partially replaced by the pink pepper flour, improving the performance. Thus, alternatives additives can be effective the for growth promoter replacement in poultry diets. In the present study, the levels of 100 and $500 \mathrm{mg} / \mathrm{kg}$ of sucupira oil showed 
interesting results and there was no rejection of consumption by the birds, and these levels could be studied as alernative for antibiotics.

Daneshmand, Sadeghi \& Karimi (2012) used a compound of garlic, shimeji-black and propolis extract that had no effect on the relative weight of organs. In this experiment, the growth promoter antibiotic also did not produce changes in the body weight variables, however the antibiotic decreased the relative weight of small intestine segments.

The results reinforce the hypothesis that the effects of the phytogenic would be dependent on the composition of the plant product. The composition of the plants is susceptible to variations according to the time and method of harvesting of the plant, state of maturation of the plant, method of conservation of the vegetable drug, duration of storage and possible synergic or antagonistic effect of the bioactive compounds (BRENES \& ROURA, 2011). In this way, each result would be specific to a given phytogenic searched.

Differences in liver and pancreas weight may be an indirect inference of the enzyme activity of these organs and may also be related to inflammatory and reactional processes. Since these activities (enzymes and toxicity) were not specifically researched in this work, only assumptions can be made that the higher levels promoted higher weights of these organs attached to the gastrointestinal tract.

After the determination of acceptable inclusion levels of broilers, it is suggested that experiments are carried out in which birds undergo microbiological challenges and stressful factors for the purpose of verify the ability to improve performance for supplementation with 100 or $500 \mathrm{mg}$ of sucupira oil, since the birds did not reject these concentrations of the product. In this study no differences were observed between control and avilamycin groups, which reinforces the need for a study with microbiological challenge, simulating a field situation. It is known that the effect of the antibiotic is more expressive in challenging situations (THOMKE \& ELWINGER, 1998), and the main effects are due to the interaction with microbiota (ALBUQUERQUE, 2005).

\section{CONCLUSION}

It was possible to conclude that it is feasible to include sucupira oil in the diet of broilers at doses of 100 or $500 \mathrm{mg} / \mathrm{kg}$ of feed.

\section{REFERENCES}

ALBUQUERQUE, R. Antimicrobianos como promotores do crescimento. In: PALERMO-NETO, J.; SPINOSA, H. DE S.; GÓRNIAK, S.L. Farmacologia aplicada à avicultura: boas práticas no manejo de medicamentos. 1. ed. São Paulo: Roca, 2005. p. 149-159.

AMAD, A. A.; MANNER, K.; WENDLER, K. R.; NEUMANN, K.; ZENTEK, J. Effects of a phytogenic feed additive on growth performance and ileal nutrient digestibility in broiler chickens. Poultry Science, v. 90, p. 2811-2811, 2011.

AOAC, 1995. Official Methods of Analysis of AOAC International, 16th ed. Association of Official Analytical Chemists, Washington, DC, USA.

BORSATTI, L.; NUNES, R. V.; SCHONE, R. A.; FRANK, R.; SCHNEIDERS, J. L.; SAVOLDI, T. L. Nutrient digestibility in diets for broilers supplemented with growth promoters. Arquivo Brasileiro de 
Medicina Veterinária e Zootecnia, v. 68, n. 1, p. 201-207, 2016.

BRENES, A. \& ROURA, E. Essential oils in poultry nutrition: Main effects and modes of action. Animal Feed Science and Technology, v. 158, p. 1-14, 2010.

BUSTAMANTE, K.G.L.; LIMA, A.D.F.; SOARES, M.L.; FIUZA, T. S., TRESVENZOL, L.M.F.; BARA, M.T.F., PIMENTA, F.C.; PAULA, J.R. Avaliação da atividade antimicrobiana do extrato etanólico bruto da casca da sucupira branca (Pterodon emarginatus Vogel) - Fabaceae. Revista Brasileira de Plantas Medicinais, v.12, n. 3, p. 341-345, 2010.

CASTANON, J.I.R. Histoty of the use of antibiotic as growth promotes in European poultry feeds. Poultry Science, v. 86, n. 11, p. 2466-2471, 2007.

CHOWDHURY, S.; MANDAL, G.P.; PATRA, A.K.; KUMAR, P.; SAMANTA, I.; PRADHAN, S.; SAMANTA, A.K. Different essential oils in diets of broiler chickens: gut microbes and morphology, immune response, and some blood profile and antioxidant enzymes. Animal Feed Science and Technology, v. 236, p. 39-47, 2018.

DANESHMAND, A.; SADEGHI, G. H.; KARIMI, A. The Effects of a Combination of Garlic, Oyster Mushroom and Propolis Extract in Comparison to Antibiotic on Growth Performance, Some Blood Parameters and Nutrients Digestibility of Male Broilers. Brazilian Journal of Poultry Science, v. 14, n. 2, p. 71-158, 2012.

DUTRA, R.C.; SILVA, P.S.; PITTELA, F.; VICCINI, L.F.; LEITE, M.N.; RAPOSO,
N.R.B. Caracterização Fitoquímica e Citogenética das sementes de Pterodon emarginatus Vogel. Revista TécnicoCientífica do IF-SC, v. 3, p. 99-109, 2012.

FASCINA, V. B.; PASQUALI, G. A. M.; CARVALHO, F. B.; MURO, E. M.; VERCESE, F.; AOYAGI, M. M.; PEZZATO, A. C.; GONZALES, E.; SARTORI, J. R. Effects of phytogenic additives and organic acids, alone or in combination, on the performance, intestinal quality and immune responses of broiler chickens. Brazilian Journal of Poultry Science, 19(3), p.497-508, 2017.

GONÇALVES, F.G.; ZANINI, S.F.; SOUSA, D.R.; SILVA, M.A.; COLNAGO, L.G. Sinergia entre aditivo vegetal e níveis crescentes de promotores de crescimento sobre o desempenho produtivo e morfometria intestinal de frangos de corte. Ciência Rural, v. 44, n. 2, p. 340-345, 2014.

HASHEMI, S. R. \& DAVOODI, H. Herbal Plants as New Immuno-stimulator in Poultry Industry: A Review. Asian Journal of Animal and Veterinary Advances, v. 7, p. 105-116, 2011.

HAZRATI, S.; REZAEIPOUR, V.; ASADZADEH, S. Effects of phytogenic feed additives, probiotic and mannanoligosaccharides on performance, blood metabolites, meat quality, intestinal morphology, and microbial population of Japanese quail. British Poultry Science, v. 61, n. 2, p.132-139, 2020.

HERNÁNDEZ, F.; MADRID, J.; GARCIA, V.; ORENGO, J.; MEGIAS, M. D. Influence of two plant extracts on broilers performance, digestibility, and digestive organ size. Poultry Science, v. 83(2):, p. 169-174, 2004. 
KHODAMBASHI, E. N.; SAMIE, A.; RAHMANI, H.R.; RUIZ-FERIA, C.A. The effect of peppermint essential oil and fructooligosaccharides, as alternatives to virginiamycin, on growth performance, digestibility, gut morphology and immune response of male broilers. Animal Feed Science and Technology, v.175, p.57-64. 2012.

KIRKPINAR, F.; BORA, H.; ÖZDEMIR G. Effects of oregano and garlic essential oils on performance, carcase, organ and blood characteristics and intestinal microflora of broilers. Livestock Science, v. 137, p. 219225, 2011.

LEICA MICROSYSTEMS LIMITED. Leica application Suite Version 2.1.0. Solms, Germany, 2012.

LORENZI, H. E. \& MATOS, F. J. A. Plantas medicinais no Brasil/ Nativas e exóticas. Nova Odessa: Instituto Plantarum. 2002. 512 p.

LUNA, L. G. Manual of the histologic staining methods of the armed forces institute of pathology. 3. ed. New York: McGraw Hill, 1968. 258 p.

NERI, A. V. Composição Florística de uma Área de Cerrado Sensu Stricto no Município de Senador Modestino Gonçalves, Vale do Jequitinhonha (MG) e Análise de Similaridade Florística de Algumas Áreas de Cerrado em Minas Gerais. Revista Árvore, v. 31, n. 6, . 1109-1119, 2007.

NOLETO, R.A.; LEANDRO, N.S.M.; MELLO, H.H.C.; CONCEIÇÃO, E.C.; ARAÚJO, I.C.S.; OLIVEIRA, E.M.; BARBOSA, A.F.C. Supplementation of copaiba or sucupira oils in broiler diets.
Revista Brasileira de Saúde e Produção Animal, v. 19, n. 1, p. 83-92, 2018.

OLIVEIRA, M.D.; MELLO, H.H.C.; STRINGHINI, J. H.; MASCARENHAS, A. G.; ARNHOLD, E.; CONCEIÇÃO, E.C.; MARTINS, J.M.S.; JÚNIOR, S. Antioxidant effect of the guava byproduct in the diet of broilers in the starter phase. Revista Brasileira de Zootecnia, v.47, p.1-8, 2018

RAMOS, L.D.S.N.; LOPES, J.B.; RIBEIRO, M.N.; SILVA, F.E.S.; MERVAL, R.R.; NORONHA ALBUQUERQUE, D.M. Aditivos alternativos a antibióticos para frangos de corte no período de 22 a 42 dias de idade. Revista Brasileira de Saúde e Produção Animal, v. 15, n. 4, p. 897-906, 2014.

ROSTAGNO, H.S.; ALBINO, L.F.T.; DONZELE, J.L; GOMES, P.C.; OLIVEIRA, R.F.; LOPES, D.C.; FERREIRA, A.S.; BARRETO, S.L.T. Tabelas brasileiras para aves e suínos: composição de alimentos e exigências nutricionais. 3 . ed. Viçosa: UFV, 2011, 252 p.

SAKOMURA, N. K. \& ROSTAGNO, H. S. Métodos de pesquisa em nutrição de monogástricos. 1. ed. Jaboticabal: Funep, 2007. 283 p.

SANTOS, A.P.; ZATTA, D.T.; MORAES, W.F.; BARA, M.T.F.; FERRI, P.H.; SILVA, M.R.R.; PAULA, J.R. Composição química, atividade antimicrobiana do óleo essencial e ocorrência de esteróides nas folhas de Pterodon emarginatus Vogel, Fabaceae. Revista Brasileira de Farmacognosia, v. 20, p. 891-896, 2010.

SARKER, M. S. K.; KIM, G. M.; YANG, C. J. Effect of green tea and biotite on performance, meat quality and organ 
development in Ross broiler. Egyptian

Poultry Science Journal, v.30(1), p. 77-88, 2010.

SCHEUERMANN, G.N.; JÚNIOR, A.C.; CYPRIANO, L.; GABBI, A.M. Aditivo fitogênico como alternativa aos promotores de crescimento em frangos de corte. Ciência Rural, v. 39, n. 2, p. 522-527, 2009.

SILVA, I.D.; TAKATSUKA, F.S.; ROCHA, M.R..; CUNHA, M.G. Efeito do extrato de sucupira (Pterodon emarginatus Vog.) sobre o desenvolvimento de fungos e bactérias fitopatogênicos. Pesquisa Agropecuária Tropical, v. 35, n. 3, p. 109-115, 2005.

SILVA, M.A.; PESSOTI, B.M.S.; ZANINI, S.F.; COLNAGO, G.L.; NUNES, L.C.; RODRIGUES, M.R.A.; FERREIRA, L. Óleo essencial de aroeira-vermelha como aditivo na ração de frangos de corte. Ciência Rural, v. 41, n. 4, p. 676-681, 2011.

Statistical Analysis System - SAS ${ }^{\circledR}$ user's guide: statistics. Cary: SAS Institute, 2004.

THOMKE, S. \& ELWINGER, K. Growth promotants in feeding pigs and poultry. II. Mode of action of antibiotic growth promotants. Annales de Zootechnie, v. 47, p.153-167, 1998.

VASCONSELOS, M.F.O que são campos rupestres e campos de altitude nos topos de montanha do Leste do Brasil? Revista Brasileira de Botânica, v. 34, n. 2, p. 241246, 2011.

VIEIRA, S.L. Consumo e preferência alimentar dos animais domésticos. 1. ed. Londrina: Phytobiotics Brasil, 2010. 315 p. 